\title{
PERAN PERLINDUNGAN SOSIAL DALAM MENGATASI KEMISKINAN DI INDONESIA: STUDI KASUS PROGRAM KELUARGA HARAPAN
}

\author{
Edi Suharto \\ Direktur Kesejahteraan Sosial Anak, Kementerian Sosial. Dosen luar biasa di Jurusan Kesejahteraan Sosial \\ Universitas Pasundan Bandung \\ Email: suharto@policy.hu
}

\begin{abstract}
ABSTRAK, Salah satu tantangan terbesar dalam pembangunan Indonesia sejak kemerdekaan adalah menanggulangi kemiskinan. Meski trennya menurun dari tahun ke tahun, namun jumlah penduduk miskin di Indonesia masih cukup besar, baik yang berada di wilayah perdesaan maupun perkotaan. Perlindungan sosial merupakan salah satu strategi penanggulangan kemiskinan yang semakin populer di Indonesia, terutama sejak kriris ekonomi menerpa negeri ini di Tahun 1997. Jika diterapkan secara tepat, perlindungan sosial dapat berimplikasi positif pada pembangunan ekonomi dan sosial suatu negara. Menggunakan metode "desk review", artikel ini menelaah peran perlindungan sosial di Indonesia dalam mengatasi kemiskinan, terutama perlindungan sosial yang menggunakan pendekatan Income support schemes (ISS) atau skema tunjangan pendapatan. Di Indonesia, pendekatan IIS ini diterapkan dalam bentuk conditional cash transfer (CCT) atau bantuan tunai bersyarat, yakni Program Keluarga Harapan (PKH). Telaah terhadap penerapan PKH di Indonesia menunjukkan bahwa program ini memberi kontribusi yang signifikan bagi pengentasan kemiskinan, khususnya dalam meningkatkan partisipasi sekolah para penerima manfaat (beneficiaries) pada pendidikan dasar dan akses mereka terhadap pelayanan kesehatan.
\end{abstract}

Keywords: Perlindungan Sosial, Kemiskinan, Kesehatan dan Pendidik

\section{ROLE OF SOCIAL PROTECTION IN THE FIGHT POVERTY IN INDONESIA: CASE STUDY PROGRAM FAMILY HOPE}

\begin{abstract}
One of the most critical challenges in Indonesia's development since independence is to overcome poverty. Although the trend has declined yearly, the number of poor people is still high in both rural and urban areas. Social protection is a poverty alleviation strategy which become more popular in Indonesia particularly since monetary crisis hit the country in 1997. Appropriate implementation of social protection provides positive contributions to social and economic development of a country. Employing desk review method, this article examines the role of social protection, especially Income Support Schemes (IIS), in reducing poverty in Indonesia, which is implemented in the form of Conditional Cash Transfer, namely "Family Hope Program" or Program Keluarga Harapan (PKH). This study on PKH shows that this program has provided significant contributions in alleviating poverty, notably in increasing school participation of beneficiaries in primary education as well as in enhancing their access to health services.
\end{abstract}

Keywords: Social Protection, Poverty, Health and Education

\section{PENDAHULUAN}

Dalam kebijakan sosial, perlindungan sosial merupakan elemen penting dalam pengentasan kemiskinan dan pengurangan depriviasi multidimensional (Suharto, 2006). Perlindungan sosial merujuk kepada proses, kebijakan dan intervensi yang sebagian besar dikembangkan oleh pemerintah guna merespon resiko ekonomi, politik dan keamanan yang dihadapi oleh penduduk - terutama penduduk miskin dan rentan. Sebagai serangkaian kebijakan, perlindungan sosial merujuk kepada apa yang dapat dicapai pemerintah dalam rangka menyediakan perlindungan bagi warga negaranya - terutama penduduk miskin dan rentan. Kebijakan publik tersebut berperan sebagai artikulasi kewajiban negara dalam memenuhi hak dasar setiap warga negaranya. Namun demikian, perlindungan sosial bukan merupakan satu-satunya pendekatan dalam program pengurangan kemiskinan. Guna pencapaian hasil yang efektif dan berkelanjutan, diperlukan kombinasi dengan pendekatan lainnya seperti misalnya penyediaan layanan sosial dan ekonomi dalam konteks pembangunan nasional (Suharto, 2009).

Meskipun dikenal sebagai negara yang memiliki sumber daya ekonomi yang potensial, Indonesia masih sangat akrab dengan kemiskinan dan pengangguran. Masyarakat miskin dan tidak memiliki pendapatan sangat rentan terhadap berbagai resiko-resiko sosial. Mulai dari minimnya pendapatan yang berujung pada kesulitan untuk mengakses hak-hak hidup yang paling mendasar hingga kebutuhan-kebutuhan lanjutan seperti pendidikan dan kesehatan. Ini adalah resiko sosial yang dihadapi oleh sebagian besar penduduk miskin yang tersebar di berbagai pelosok nusantara. Pada titik ini negara memiliki tanggung jawab besar untuk memberikan perlindungan warganya terhadap resiko-resiko sosial tersebut (Purwoko, 2009). Tanggung jawab tersebut makin kuat untuk diperankan baik karena tuntutan ideologis maupun konstitusional.

Secara ideologis, terutama jika dikaitkan dengan konsep negara kesejahteraan (welfare state), kesejahteraan warga masyarakat adalah tanggung jawab negara (Suharto, 2008). Dalam konsep negara kesejahteraan, kebijakan publik yang diterapkan oleh pemerintah tidak hanya bersifat pelayanan (service) atau bantuan (charity) namun juga perlindungan (protection) atau pencegahan (prevention) pada masalah-masalah sosial. Ideologi inilah yang sesungguhnya telah 
menjadi jantung dari konstitusi negara kita (Suharto, 2006). Sehingga kalau kita cermati misalnya dalam Undang-Undang Dasar 1945 secara eksplisit mengamanahkan negara dalam tanggung jawabnya untuk mensejahterakan seluruh warga masyarakat tanpa terkecuali.

Artikel ini bertujuan untuk mendeskripsikan implementasi Program Keluarga Harapan (PKH) sebagai sebuah studi kasus skema perlindungan sosial untuk mengentaskan kemiskinan di Indonesia. PKH merupakan bagian dari Income Support Schemes (skema tunjangan pendapatan) atau yang kemudian di Indonesia populer dengan Conditional Cash Transfer (CCT) (bantuan tunai bersyarat). Artikel ini pada dasarnya ingin menjawab tiga masalah pokok sebagai berikut: Pertama, bagaimana pendekatan perlindungan sosial dalam mengatasi kemiskinan; kedua, bagaimana implementasi PKH di Indonesia sebagai bagian dari pendekatan perlindungan sosial ini; dan terakhir, bagaimana dampak PKH terhadap pembangunan kesejahteraan sosial terutama di bidang pendidikan dan kesehatan.

Kebijakan perlindungan sosial merupakan bagian dari serangkaian kebijakan pembangunan makroekonomi, program ketenagakerjaan, serta kebijakan pendidikan dan kesehatan yang lebih luas, yang dikembangkan untuk mengurangi resiko dan depriviasi serta untuk mendorong pertumbuhan yang setara dan berkelanjutan. Kondisi ini tidak hanya memungkinkan kelompok "miskin aktif" (active poor) untuk berpartisipasi secara lebih produktif dalam aktivitas ekonomi, melainkan juga memungkinkan "kelompok miskin yang kurang aktif" (less-active poor) untuk 'berkontribusi' pada stabilitas sosial - yang pada gilirannya dapat menciptakan keuntungan bagi masyarakat secara luas (Shepherd et al, 2004). Pada prinsipnya, tujuan perlindungan sosial adalah untuk menciptakan proses pembangunan yang memungkinkan secara ekonomi dan sosial, serta dapat diterima secara politis melalui upaya pencegahan, mitigasi serta upaya mengatasi dampak negatif dari pembangunan itu sendiri.

Secara konseptual perlindungan sosial adalah 'tindakan publik yang diambil untuk mengurangi kemiskinan, kerentanan dan ketidaksetaraan' (UNESCAP, 2012). Secara operasional perlindungan sosial dapat didefinisikan sebagai serangkaian inisiatif pemerintah yang didesain untuk menyediakan empat skema utama: bantuan sosial, pelayanan sosial, asuransi sosial, dan kebijakan pasar kerja.

- Bantuan sosial adalah layanan publik yang diberikan kepadapendudukdan rumah tanggayang sangatmiskin, terutama dengan menggunakan prinsip solidaritas vertikal dan oleh karenanya tidak mempertimbangkan kontribusi ataupun premi dari penerima manfaat;

- Pelayanan sosial adalah salah satu jenis pelayanan kesejahteraan yang terutama didesain untuk kelompok-kelompok yang membutuhkan perawatan khusus atau yang mendapat penolakan akses terhadap rangkaian pelayanan dasar;

- Asuransi sosial adalah skema yang dikembangkan untuk melindungi masyarakat terhadap resiko dan konsekuensi guncangan pendapatan berdasarkan kontribusi maupun premi yang dibayarkan sebelumnya;

- Kebijakan pasar kerja merupakan intervensi publik yang bertujuan untuk memastikan standar ketenagakerjaan bagi kelompok masyarakat yang kurang beruntung.

Perlindungan sosial terkait dengan penyebab kemiskinan dan kerentanan di masa kini dan masa depan. Oleh sebab itu, perlindungan sosial dapat menyediakan sokongan bagi kemiskinan dan depreviasi, terutama bagi mereka yang termasuk ke dalam kategori 'sangat miskin' dengan membantu mereka untuk keluar dari kemiskinan serta mencegah 'kerentanan sosial dan ekonomi' agar tidak terjatuh ke kondisi di bawah garis kemiskinan. Skema perlindungan sosial dapat meningkatkan kapabilitas dan pendapatan riil kelompok miskin dan rentan - yang dicapai melalui serangkaian program perbaikan mata pencaharian.

\section{METODE}

Tulisan ini menggunakan metode "induksi analitik" (analytic induction), yakni suatu penelitian kualitatif yang berangkat dari kasus-kasus yang bersifat khusus untuk kemudian dirumuskan menjadi model, konsep, teori, prinsip, proposisi atau definisi yang bersifat umum (Mulyana, 2002). Pengumpulan data dilakukan berdasarkan "desk review" yang melibatkan kajian literatur dan analisis data sekunder. Selain berdasarkan pada pengamatan dan keterlibatan langsung penulis dalam program PKH di Indonesia, data utama tulisan ini dikembangkan dari riset penulis tentang Social Protection in Asia and the Pacific: The Case of Income Support Schemes in ASEAN yang telah dua kali diseminarkan saat menjadi konsultan di UNESCAP (2011-2013).

\section{HASIL DAN PEMBAHASAN}

\section{Perlindungan Sosial Sebagai Strategi Penang- gulangan Kemiskinan}

Perlindungan sosial di Indonesia dirasakan semakin penting, terutama setelah krisis ekonomi menerjang negara ini di tahun 1997 (Suharto, 2006). Saat krisis ekonomi Asia menghantam kawasan ASEAN di tahun 1990-an, ketergantungan pada sistem perlindungan tradisional berbasis keluarga, dan pada beberapa kasus, kurang berkembangnya infrastruktur guna mengelola program-program perlindungan sosial, menyebabkan kegagalan banyak pemerintah dalam merespon kebutuhan warga negaranya secara efektif.

Krisis ekonomi yang diikuti menurunnya performa negara-negara 'ajaib' di ASEAN menunjukkan bahwa pertumbuhan dan promosi kebijakan makroekonomi semata tidaklah cukup untuk pengentasan kemiskinan yang berkelanjutan. Pada saat terjadinya krisis ekonomi, mayoritas penduduk di kawasan Asia Tenggara, terutama mereka yang bekerja pada sektor ekonomi informal, tidak terlindungi oleh skema perlindungan sosial formal. Saat sistem perlindungan sosial tradisional di Indonesia terbukti tidak mampu 
beradaptasi terhadap permintaan ekonomi pasar liberal, erosi yang terjadi bertahap menggerogoti jaring pengaman tradisional yang ada, yaitu jaring pengaman keluarga dan komunitas.

Di Indonesia, inisiatif penguatan sistem perlindungan sosial semakin mengemuka dalam konteks strategi pengentasan kemiskinan. Sebagai bentuk komitmennya, beberapa perundangan dan peraturan yang mengangkat pentingnya perlindungan sosial, telah pula ditetapkan oleh Pemerintah Indonesia. Beberapa peraturan tersebut, antara lain:

- UUD 1945 menekankan pada perlindungan sosial. Ayat kedua dari Pasal 34 menyatakan bahwa negara mengembangkan sistem jaminan sosial bagi seluruh rakyat.

- UU No 40 tahun 2004 tentang Sistem Jaminan Sosial Nasional (SJSN): perlindungan sosial meliputi pensiun dan tunjangan masa tua; tunjangan kesehatan; tunjangan kecelakaan kerja; dan tunjangan kematian;

- UU No 11 tahun 2009 tentang Kesejahteraan Sosial: setiap warga negara harus memperoleh kebutuhan hidup dasar serta layanan sosial melalui rehabilitasi sosial, jaminan sosial, perlindungan sosial dan pemberdayaan sosial.

Berkait hal ini, pemerintah Indonesia melakukan percepatan pengurangan kemiskinan dalam beberapa klaster. Presiden Susilo Bambang Yudhoyono telah mendeklarasikan bahwa pengurangan kemiskinan merupakan prioritas utama pembangunan pada masa pemerintahannya. Pemerintah berencana untuk mencapai tujuan ini melalui penguatan pertumbuhan ekonomi dan penciptaan lapangan kerja, dan pada saat yang bersamaan melanjutkan strategi pengentasan kemiskinan. Strategi ini diartikulasikan dalam tiga klaster:

- Klaster I memfokuskan pada bantuan sosial berbasis rumah tangga. Beberapa program yang dikembangkan dalam klaster ini antara lain Bantuan Operasional Sekolah (BOS) dan BSM; Jamkesmas; Raskin dan Program Keluarga Harapan (PKH). Klaster ini bertujuan untuk mengurangi kemiskinan dan memperbaiki kualitas SDM, terutama bagi penduduk miskin.

- Klaster II menekankan pada program-program pemberdayaan masyarakat. Program Nasional Pemberdayaan Masyarakat (PNPM) Mandiri dan Kelompok Usaha Bersama (KUBE) adalah beberapa program yang dikembangkan dalam klaster kedua ini. Tujuan PNPM Mandiri, misalnya, adalah untuk memperbaiki kesejahteraan masyarakat serta memberikan kesempatan kerja yang lebih besar bagi kelompok miskin.

- Klaster III bertujuan untuk memperluas kesempatan ekonomi bagi rumah tangga berpendapatan rendah serta untuk mencapai inklusivitas ekonomi bagi lebih banyak penduduk Indonesia. Program yang didesain pada klaster ini antara lain Kredit Usaha Rakyat (UKR) yang menyediakan kredit usaha bagi kelompok miskin tanpa bunga. UKR dikembangkan di bawah Kementerian Koperasi dan Usaha Kecil dan Menengah.

Selain PKH, di Klaster I terdapat tiga bantuan sosial yang diluncurkan oleh Pemerintah Indonesia, yaitu:

- Bantuan Siswa Miskin (BSM) - sekarang dirubah menjadi Subsidi Siswa Miskin (SSM). SSM adalah bantuan tunai bersyarat yang dikembangkan oleh Direktorat Pendidikan Dasar, Kementerian Pendidikan dan Kebudayaan yang menyasar siswa dari keluarga miskin. Didanai dari APBN, program ini telah menjangkau 2,246,800 siswa miskin di tahun 2010 dan berencana untuk meng-cover lebih dari 6 juta siswa di tahun 2012 (GIZ 2012).

- Jaminan Kesehatan Masyarakat (Jamkesmas) adalah asuransi kesehatan bagi penduduk miskin yang diluncurkan oleh Kementerian Kesehatan. Berdasarkan data resmi, sebanyak 18.2 juta rumah tangga dengan total 76.4 juta jiwa - sekitar sepertiga dari total penduduk - telah dilindungi oleh Jamkesmas, menjadikan Jamkesmas sebagai skema layanan kesehatan terbesar di Indonesia. Skema yang diperkenalkan pada tahun 2008 ini merupakan hasil pengembangan dari Asuransi Kesehatan Masyarakat Miskin (Askeskin) yang diluncurkan di tahun 2004 (GIZ, 2012).

- Program Beras Miskin (Raskin) yang pelaksanaannya dari tahun 2005-2012 berada di bawah tanggung jawab Badan Urusan Logistik (Bulog) dan sejak tahun 2013 dilaksanakan di bawah Dirktorat Jenderal Pemberdayaan Sosial, Kementerian Sosial. Program subsidi beras ini menyasar rumah tangga hampir miskin, miskin dan sangat miskin sebagai targetnya. Selama tahun 2005-2009, Raskin berhasil menyalurkan 1.6hingga 3.2 juta ton beras. Rumah tangga miskin hanya perlu membayar Rp 1,000/kg di tahun 2007 dan Rp 1,600/kg di tahun 2008. Program telah berhasil tidak hanya membantu rumah tangga miskin untuk memperkuat keamanan pangan mereka, tetapi juga menjaga kestabilan harga. Di tahun 2010, sebanyak 17.5 juta rumah tangga miskin ditargetkan menjadi penerima manfaat program ini. Alokasi dana untuk program ini mencapai Rp 12.9 triliun di tahun 2009 dan 13.1 triliun di tahun 2010 (World Bank, 2010).

\section{Cakupan dan Manfaat PKH}

Dimulai tahun 2007, Program Keluarga Harapan (PKH) merupakan program conditional cash transfer (CCT) atau bantuan tunai bersyarat yang bertujuan untuk memperbaiki kualitas pembangunan manusia, terutama anak-anak dari rumah tangga sangat miskin. Tujuan khusus dari PKH adalah untuk memperbaiki kondisi sosial ekonomi penerima bantuan; mempertinggi tingkat pendidikan; memperbaiki status kesehatan dan gizi ibu hamil, nifas dan balita; serta memperbaiki akses dan kualitas layanan pendidikan dan kesehatan.

Di Indonesia, keluarga penerima manfaat memperoleh bantuan bersyarat berdasarkan status pendidikan dan 
kesehatan anak-anak mereka. PKH memberikan bantuan kepada rumah tangga sangat miskin berdasarkan tingkat partisipasi mereka dalam program perbaikan gizi dan kesehatan, serta tingkat kehadiran di sekolah. Bantuan tunai akan diperoleh rumah tangga yang memenuhi kewajiban mereka di bidang pendidikan dan kesehatan. Bantuan ini diberikan kepada kelompok perempuan di dalam keluarga karena dipercaya bahwa perempuan lebih cenderung menggunakan uang yang mereka miliki untuk digunakan membeli barang atau jasa yang bermanfaat bagi anak-anak mereka. Tidak terdapat larangan mengenai penggunaan dana, namun dalam rangka memperbaiki kondisi penghidupan penerima bantuan, disarankan agar bantuan yang diperoleh digunakan untuk kebutuhan keluarga. Bantuan inipun dibayarkan kepada ibu atau perempuan dewasa lainnya di dalam rumah tangga, seperti bibi atau nenek.

Pada Tahun 2007, PKH mencakup 387.928 rumah tangga sangat miskin (RTSM) yang memiliki pendapatan kurang dari Rp 480,000/bulan (USD 53/bulan). Penerima bantuan PKH meningkat hingga 816,000 RTSM di tahun 2010 dan kembali bertambah menjadi 1,51 juta rumah tangga di tahun 2012. Ini berarti, PKH mencakup 43\% dari total RTSM di Indonesia (3.5 juta), 5.02\% dari penduduk miskin (30.02 juta, 2010) dan 0.58\% dari total penduduk negara ini (259 juta, 2010). Angka ini akan terus menerus ditingkatkan hingga tahun 2014, hingga mencapai 3 juta penerima manfaat di 33 provinsi, 497 kabupaten dan 3,342 kecamatan di Indonesia (web PKH, 2012).

Dengan melibatkan tiga kementerian - Kementerian Sosial, Kementerian Kesehatan dan Kementerian Pendidikan dan Kebudayaan - di bawah Kementerian Koordinator Kesejahteraan Sosial, Kementerian Agama dan PT Pos Indonesia, PKH menjadi program nasional terbesar yang mendapat dukungan penuh dari Pemerintah Indonesia. Sebagai bantuan tunai bersyarat, $\mathrm{PKH}$ menyediakan bantuan sosial kepada penerima manfaat dengan mensyaratkan pemenuhan kewajiban oleh rumah tangga penerima (Tabel 1).

Tabel 1: Protokol Pelayanan Pendidikan dan Kesehatan Bagi Peserta PKH

Sumber: Diolah dari Ayala (2010)

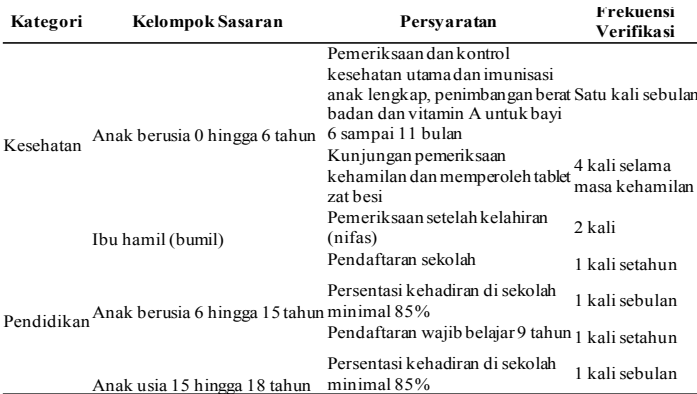

Dalam satu tahun, periode pembayaran uang tunai dilakukan sebanyak empat kali. Jadwal pembayaran di setiap kecamatan ditentukan oleh UPPKH kabupaten/ kota setelah berkoordinasi sebelumnya dengan PT Pos - lembaga yang berdasarkan kesepatakan, ditunjuk sebagai penanggung jawab pembayaran bantuan PKH kepada peserta. Sistem informasi manajemen yang canggih dikembangkan untuk mendukung program ini. Jumlah bantuan yang diperoleh peserta ditentukan berdasarkan status terkini mereka jumlah anak sekolah, status kehamilan serta tingkat kunjungan ke pusat pendidikan dan kesehatan (lihat Tabel 4). Besaran bantuan yang diterima bervariasi, dari bantuan minimal sebesar Rp 600,000 (USD 65) hingga bantuan maksimal Rp 2,200,000 (USD 235) per tahun per RTSM.

\begin{tabular}{lc} 
Tabel 2: Skenario bantuan PKH \\
\hline \multicolumn{1}{c}{ Skenario pembayaran } & $\begin{array}{c}\text { Jumlah bantuan yang } \\
\text { diterima RTSM(Rp) }\end{array}$ \\
\hline Bantuan tetap & 200 \\
Bantuan bagi RTSM yang memiliki: & 800 \\
a. Anak usia di bawah 6 tahun atau ibu hamil & 400 \\
b. Anak usia sekolah dasar (SD) & 800 \\
c. Anak usia sekolah menengah pertama (SMP) & $1,390,000$ \\
Rata-rata bantuan yang diterima RTSM & 600 \\
Bantuan minimal yang diterima RTSM & $2,200,000$ \\
Bantuan maksimal yang diterima RTSM & \\
Sumber: Pedoman Umum PKH, 2011
\end{tabular}

Dalam praktiknya, PKH menjalankan preferensi gender dalam penyaluran bantuan. Penarikan bantuan yang diterima hanya dapat dilakukan oleh perempuan dewasa di dalam keluarga (misalnya ibu, bibi, nenek atau kerabat perempuan lainnya). Pengecualian dari ketentuan di atas dapat dilakukan pada kondisi tertentu - misalnya bila tidak ada perempuan dewasa dalam keluarga maka pengambilan bantuan dapat digantikan oleh kepala keluarga (contohnya ayah atau saudara laki-laki) - dengan didampingi oleh pendamping $\mathrm{PKH}$. Pendamping $\mathrm{PKH}$ bertanggung jawab untuk menangkap berbagai perubahan terkait dengan status kelayakan peserta, perubahan struktur rumah tangga peserta, perubahan status pendidikan dan kesehatan serta status kunjungan ke fasilitas pendidikan dan kesehatan yang dilakukan peserta.

Kunjungan ke rumah peserta serta pemeriksaan ulang kepada tetangga peserta dilakukan untuk memastikan informasi serta guna menghindari terjadinya pemalsuan data peserta. Guru, selain memonitor jumlah kunjungan anak peserta $\mathrm{PKH}$, juga memverifikasi status pendaftaran anak serta memastikan kelulusannya. Kader posyandu dan pustu mengkonfirmasi status kehamilan, kelahiran, kematian bayi, serta memonitoring pelaksanaan kunjungan rutin untuk pemeriksanaan kesehatan. Pada tahun 2011, UPPKH mempekerjakan 4,823 pendamping - empat kali lebih besar dari jumlah pendamping di tahun 2007 yang berjumlah 1,305 (web PKH, 2012). Sejak perluasan PKH di seluruh 33 provinsi di tahun 2012, jumlah pendamping program ini telah mencapai 6,000 orang - 44\% pendamping laki-laki dan $56 \%$ perempuan. Pendamping ini kebanyakan berlatar belakang pendidikan ilmu sosial. Penambahan jumlah pendamping merupakan konsekuensi logis dari peningkatan jumlah peserta dan cakupan program (GIZ, 2012).

PKH berdampak pada bidang pendidikan dan kesehatan serta pada belanja rumah tangga per kapita. Bidang pendidikan dan kesehatan itu sendiri sesungguhnya memberi kontribusi yang signifikan terhadap indeks pembangunan manusia (human development index) - di samping tentu saja pendapatan 
ekonomi. Namun demikian, meskipun bantuan tunai mempengaruhi pasar lokal melalui penciptaan peningkatan permintaan yang dapat memicu respon berupa penyediaan barang dari produsen lokal, dampak bantuan tunai dalam ekonomi lokal relatif kecil. Selain itu, tidak pula terdapat bukti yang menguatkan bahwa bantuan tunai dapat meningkatkan kesejahteraan rumah tangga (Kebede, 2006).

Dalam berbagai evaluasi, dampak PKH dalam bidang pendidikan masih relatif rendah, hal ini terutama dilatarbelakangi oleh kehadiran sekolah pada anak berusia 6-15 tahun yang memang sudah tinggi. Sehingga kontribusi $\mathrm{PKH}$ terhadap peningkatan kehadiran siswa tersebut hanya 1.79 persen. Peningkatan yang rendah dalam bidang pendidikan ini setidaknya disebabkan oleh tiga faktor (Bappenas, 2009): Pertama, partisipasi masyarakat pada sekolah dasar sudah tinggi. Karena itu, meskipun terjadi kenaikan maka tidak begitu signifikan. Kedua, jadual pembayaran kurang pas dengan jadual pendaftaran sekolah (April-Mei). Kendala teknis semacam ini cukup berpengaruh terhadap partisipasi anak dalam mengikuti pendidikan di sekolah. Terakhir, jumlah pembayaran tidak cukup untuk membiayai pendaftaran sekolah.

Namun demikian, meskipun jika diprosentasekan dampak PKH di bidang pendidikan ini relatif rendah, sesungguhnya tetap ada peningkatan dalam bidang pendidikan ini. Selain itu, berdasarkan hasil survey lanjutan di 2009, tingkat belanja rumah tangga peserta PKH per kapita meningkat hingga 44\% dibandingkan sebelumnya. Belanja layanan kesehatan dan pendidikan per kapita pun meningkat, masing-masing hingga $91 \%$ dan 64\% (Bappenas, 2009). Ini artinya beneficiaries dari program PKH telah memiliki tanggungjawab dan kesadaran terhadap keluarga mereka untuk memperoleh pendidikan yang lebih memadai.

Adanya kesadaran dan tanggung jawab dari masyarakat yang menjadi beneficiaries program PKH ini tidak terlepas dari peran pendamping PKH. Penelitian SMERU (2011) tentang dampak PNPM Generasi dan PKH di Jawa Barat dan Nusa Tenggara Timur (NTT) menunjukkan bahwa para pendamping $\mathrm{PKH}$ telah menjalankan peranannya dalam mendorong kesadaran keluarga penerima program untuk memberikan perhatian yang lebih terhadap anak-anaknya dalam bidang pendidikan. Bahkan dalam penelitian tersebut disebutkan bahwa para orang tua telah memiliki komitmen terhadap pentingnya pendidikan bagi anak-anak mereka dan tetap berkomitmen terhadap layanan pendidikan meskipun bantuan telah dihentikan. Yang menarik adalah seperti terjadi di daerah pedalaman NTT program PKH ini telah berhasil menumbuhkan kesadaran dari kedua orang tua untuk mensekolahkan anak. Jadi kesadaran tidak hanya tumbuh pada sosok ibu sebagaimana menjadi beneficiaries inti program ini, akan tetapi juga pada para ayah.

Evaluasi terhadap dampak program CCT di beberapa negara menunjukkan bahwa program ini memberikan dampak positif pada layanan kesehatan di area pencegahan. Kondisi yang serupa dapat pula ditemui pada implementasi PKH. Tidak sedikit hasil evaluasi yang menunjukkan trend positif terkait dampak ini, seperti beberapa laporan berikut ini: Final evaluation report on Social Security Program : Program Keluarga Harapan 2009 (BAPPENAS); Report on PKH Spot Check in 7 Districts 2011 (TNP2K); PKH PER Report Draft (World Bank, 2011); PKH final report on Spot Check PKH 200 (Ministry of Social Affairs, PKH); dan evaluasi-evaluasi lainnya. Hasil evaluasi Bappenas (2009) misalnya menunjukkan bahwa PKH meningkatkan angka kunjungan kesehatan bagi bayi di bawah usia tiga tahun hingga 36\% serta meningkatkan jumlah kunjungan kesehatan secara umum sebesar 30\%. PKH juga berhasil meningkatkan deteksi perkembangan anak dan imunisasi sebanyak masing-masing 5\% dan $0.3 \%$.

Sedangkan evaluasi TNP2PK (2011) juga menunjukkan dampak positif PKH terhadap kesehatan ini. Seperti jumlah kunjungan ibu hamil/ menyusui terhadap fasilitas kesehatan meningkat 7-9 persen. Setelah anak dilahirkan pun ada peningkatan khususnya terhadap berat badan bayi yakni antara 1522 persen. PKH juga berdampak pada tenaga kerja kesehatan professional maupun fasilitas kesehatannya di mana masing-masing meningkat 6 dan 5 persen. Oleh karena itu, dampak PKH ini lebih meyakinkan pada wilayah yang lebih baik fasilitas kesehatannya.

Peningkatan juga terjadi pada rumah tangga penerima program PKH terhadap pengeluaran bidang kesehatan. Terutama hal ini jika dibandingkan dengan rumah tangga di daerah yang belum mendapatkan program PKH. Perbedaannya ternyata cukup signifikan. Pengeluaran rumah tangga terhadap makanan berprotein tinggi misalnya, meningkat hingga 7 persen. Pengeluaran rumah tangga terhadap bidang kesehatan ini meningkat bahkan hingga 65 persen. Total pengeluaran beneficiaries meningkat hingga 10 persen dibandingkan dengan pengeluaran sebelumnya.

\section{SIMPULAN}

Saat ini, jaring pengaman sosial di Indonesia umumnya terdiri dari subsidi makanan dan kesehatan yang bersifat sementara dan semi permanen, serta beasiswa bagi pendidikan. PKH mempromosikan strategi komprehensif yang nenawarkan perlindungan dan promosi hak asasi manusia. Adalah penting untuk memastikan bahwa PKH tidak hanya dipandang sebagai sebuah program jaring pengaman sosial semata, melainkan juga sebagai elemen penting bagi strategi jangka panjang Pemerintah Indonesia yang bertujuan untuk membangun skema tunjangan pendapatan yang menyeimbangkan perlindungan dan kesempatan dalam membantu kelompok miskin dan rentan untuk menghadapi kondisi kemiskinan yang terjadi serta mendorong upaya keluar dari jerat kemiskinan. Hal ini terutama dicapai melalui dorongan informasi modal manusia dan peningkatan kesempatan ekonomi bagi masyarakat miskin.

PKH merupakan program kompleks yang masih menghadapi beragam tantangan dalam pelaksanaannya. Sebagian fungsi program - termasuk 
pemutakhiran dan validasi data, pembayaran, verifikasi komitmen, pemberian layanan, diseminasi dan peningkatan kapasitas - telah dilakukan. Namun demikian, keseluruhan elemen tersebut tetap perlu ditingkatkan. Jika tidak dijaga dan diorganisir secara efektif, beberapa tantangan yang ditemukan dapat menghambat pencapaian tujuan PKH.

PKH perlu memperhatikan beberapa area implementasi yang perlu diperbaiki. Area tersebut antara lain evaluasi dan diseminasi, mekanisme pengaduan, serta koordinasi di antara pihak terkait. Kegiatan evaluasi dan diseminasi harus menjadi bagian yang integral pada keseluruhan program, yang dilaksanakan secara terus menerus. Diseminasi memainkan peran penting, terutama dalam memperbaiki kualitas dan dampak dari proses serta hasil program. Lebih lanjut, mekanisme pengaduan dalam program berperan sebagai sarana penting dalam menyediakan umpan balik bagi PKH. Area ini perlu diperkuat dalam rangka memastikan efektifnya layanan yang telah diberikan kepada penerima manfaat.

Perbaikan terhadap manajemen lintas sektor dan lintas tingkat kerja sama merupakan hal penting yang perlu diperhatikan dalam pelaksanaan PKH. Hubungan yang telah terjalin di antara struktur tingkat pusat sebagai steering committee, dan struktur lokal masih mengalami tantangan dalam hal penciptaan kerja sama yang lancar - terutama dalam bidang penyediaan layanan dan verifikasi komitmen peserta PKH. Lebih lanjut, rasa memiliki terhadap program ini tetap perlu dipertahankan di antara berbagai pihak dan kementerian yang terlibat dalam PKH. Sebagai koordinator kementerian, Kementerian Sosial diharapkan dapat memperkuat kerja sama horizontal dengan kementerian dan pihak lain yang mendukung program, serta koordinasi vertikal dengan pemerintah daerah. Guna menjaga efektivitas koordinasi, kerjasama horizontal maupun vertikal tersebut perlu dirampingkan.

Sebagai program nasional yang didukung oleh pekerja sosial terlatih dan sistem informasi manajemen terdepan, PKH memiliki kesempatan untuk menginisiasi pengembangan sistem perlindungan sosial yang lebih komprehensif - misalnya seperti mengkaitkan peserta PKH kepada program bantuan sosial lainnya yang tersedia di Indonesia. Ide besarnya adalah untuk mengembangkan serangkaian intervensi komplementer yang mampu membidik profil kemiskinan yang beragam di seluruh negeri. Cakupan PKH yang luas sangatlah strategis, dan karenanya perlu dilengkapi oleh elemen pendukung lainnya - seperti mekanisme program yang tertata dengan baik, yang menyasar penduduk paling rentan yang tidak menikmati dampak pertumbuhan ekonomi; inisiatif pengembangan komunitas yang kuat - dan jika memungkinkan, skema kerja publik sementara - yang membangun kesempatan sosioekonomi; serta inisiatif promosi usaha kecil dan menengah langsung berbasis individu yang kuat. *

\section{DAFTAR PUSTAKA}

Ayala (2010). Program Keluarga Harapan (PKH): Operational Assessment Report. Jakarta: GIZ

BAPPENAS (2009), Final evaluation report on Social Security Program: Program Keluarga Harapan.
Collins, E.F and Bahar, E (1995). Malu: Shame, Gender, Hierarchy, and Sexuality. Athens, $\mathrm{OH}$ : Ohio University (unpublished).

GIZ (2012). Concept Note on PKH Exit Strategy. Didistribusikan di Kementerian Sosial RI secara terbatas

Hanlon, Barrientos and Hulme (2010). Just Give Money to the Poor: The Development Revolution from the Global South. Kumarian Press

Kementerian Sosial (2011a). Pedoman Umum PKH 2011. Jakarta: Kementerian Sosial RI

Kementerian Sosial (2011a). Buku Kerja PKH 2011. Jakarta: Kementerian Sosial RI

Karman, Yongki (2012). Sejarah Masa Depan. http:// wartadetik.blogspot.com/2012/01/sejarah-masadepan.html

Laiglesia, Juan R. and Christian Morrisson (2008). Household Structures and Savings: Evidence from Household Surveys. France: OCED Development Centre

Mulyana, Deddy (2002). Metodologi Penelitian Kualitatif, Paradigma Baru Ilmu Komunikasi dan Ilmu Sosial Lainnya. Bandung: PT Remaja Rosdakarya.

Nishino, Yoshimi dan Gabriele Koehler (2011). Social Protection in Myanmar: Making the Case for Holistic Policy Reform. IDS Working Paper Volume 2011 No 386. UK: IDS

Prakarsa (2011). Belanja Sosial: Potret Buram Belanja Sosial APBN 2010. Jakarta: Prakarsa.

Purwoko, Bambang (2009). Social Protection Rebuilding in Indonesia: Process and Challenges. Paper presented on GTZ Conference on growth quality on social protection system held in New Delhi on 14-18 September 2009.

Rawlings, L and Rubio, G (2005). Evaluating the Impact of Conditional Cash Transfer Programs. The World Bank Research Observer, vol. 20, no. 1 (Spring 2005)

SMERU (2011). Qualitative Impact Study for PNPM Generasi and PKH on the Provision and the Utilization of Maternal and Child Health Services and Basic Education Services in the Provinces of West Java and East Nusa Tenggara. Jakarta: SMERU

Suharto, Edi (2006). Membangun Masyarakat Memberdayakan Rakyat. Bandung: Refika Aditama

Suharto, Edi (2008). Kebijakan Sosial sebagai Kebiajakan Publik (cetakan kedua). Bandung: Alfabeta

Suharto, Edi(2009). Kemiskinan dan Perlindungan Sosial di Indonesia: Menggagas Model Jaminan Sosial Universal Bidang Kesehatan. Bandung: Alfabeta

Suharto, Edi, Juni Thamrin, Michael Cuddy and Eammon Moran (2006), Strengthening Social 
Protection Systems in ASEAN, Galway: Galway Development Services International (GDSI)

UNDP (2011). Human Development Report: Sustainability and Equity, A Better Future for All. New York: UNDP

UNESCAP (2012). Research Framework for the Analysis of Social Protection focusing on Income Support Schemes in Asia and the Pacific. Bangkok: UNESCAP

Wetterberg, A., Sumarto, S. and Pritchett, L. (1999). A National Snapshot of the Social Impact of Indonesia's Crisis. Bulletin of Indonesian Economic Studies, 35(3), 145-152.

Worl Bank (2011), PKH PER Report Draft

\section{Website}

http://www.tradingeconomics.com/indonesia/gdpgrowth diakses pada 12 Februari 2012

http://pkh.depsos.go.id diakses pada 28 Maret 2012

http://www.worldbank.org diakses pada 27 Desember 2011

\section{Presentasi}

Kemenkokesra: Kementerian Koordinator Kesejahteraan Rakyat (2012). Sinergisitas PKH dengan Klaster dan Program Bantuan Sosial. Dipresentasikan pada Rapat Koordinasi Nasional PKH. Bandung, 21 Maret 2012.

Kemensos (2013). Perluasan dan Transformasi PKH. Dipresentasikan di TNP2K Jakarta, 11 Maret 2013

Suharto, Edi (2011). Social Protection for Children in Indonesia: Situation Analysis. Dipresentasikan pada workshop ILO. Jakarta, December 2011. 